\title{
IMPLEMENTASI LEARNING VECTOR QUANTIZATION (LVQ) UNTUK PENGENAL POLA SIDIK JARI PADA SISTEM INFORMASI NARAPIDANA LP WIROGUNAN
}

\author{
Djalu Ranadhi, Wawan Indarto, Taufiq Hidayat \\ Jurusan Teknik Informatika, Fakultas Teknologi Industri, Universitas Islam Indonesia \\ Jl. Kaliurang Km. 14 Yogyakarta 55501 \\ Telp. (0274) 895287 ext. 122, Faks. (0274) 895007ext. 148 \\ E-mail:wawan@fti.uii.ac.id, taufighid@fti.uii.ac.id
}

\begin{abstract}
ABSTRAK
Penelitian ini membuat sebuah sistem informasi narapidana untuk LP Wirogunan, yang dilengkapi dengan sistem pengenal pola sidik jari. Proses pelatihan data sidik jari menggunakan Jaringan Syaraf Tiruan metode Learning Vector Quantization (LVQ). Metode ini akan menghitung jarak antara bobot awal dengan data pelatihan, sehingga pada akhir iterasi akan ditemukan bobot akhir tiap kelas/data. Dalam proses pencocokan atau dalam sisem ini dipakai untuk proes pencarian, maka sistem akan mencari jarak terpendek antara data input baru sidik jari dengan bobot akhir tiap kelas. Kemudian akan dianalisis mengenai keberhasilan sistem dalam mengenali pola sidik jari yang baru diinputkan, serta hubungannya dengan banyaknya epoh yang digunakan serta banyaknya waktu yang diperlukan. Dari hasil pengujian terhadap metode yang digunakan dalam proses pelatihan serta pencocokan pola sidik jari, maka diperlukan waktu yang cukup lama dalam proses pelatihan maupun pencocokan. Namun dari segi keberhasilan mengenali pola sidik jari, metode ini memiliki keberhasilan yang sangat tinggi. Dengan menggunakan 20 epoh dan $a=0.05$, maka keberhasilan pencocokan mencapai $60 \%$.
\end{abstract}

Kata kunci: sidik jari, lvq, narapidana

\section{PENDAHULUAN}

\subsection{Latar belakang masalah}

Sidik jari manusia adalah pola kulit pada ujung jari dan ibu jari. Sidik jari dapat digunakan untuk mengenali identitas orang yang memilikinya karena bentuknya khas untuk setiap orang. Tidak berubah seumur hidup seseorang dan sangat sulit membuat tiruannya. Oleh karena itu, sidik jari sebagai salah satu masalah kompleks yang tidak memiliki model matematis yang jelas akan dijadikan sebagai bahan masukan Jaringan Syaraf Tiruan (JST). Salah satu metode yang dapat melakukan proses pengenalan pola sidik jari dalam JST adalah metode Learning Vector Quantization (LVQ). LVQ sendiri merupakan salah satu metode dalam JST untuk melakukan pembelajaran pada lapisan kompetitif yang terawasi.

Lembaga Pemasyarakatan (LP) merupakan institusi pemerintah yang memiliki tugas membina para narapidana dalam menjalani hukuman. Salah satu LP yang terdapat di Jogjakarta adalah LP Wirogunan. Dalam menangani 
administrasi narapidana, LP Wirogunan dihadapkan pada proses penyimpanan dan pencarian data narapidana yang masih menggunakan sistem konvensional dan belum terkomputerisasi. Dikarenakan instansi pemerintah dituntut mengambil keputusan serba cepat dan akurat, maka diperlukan suatu sistem komputer yang dapat mendukung jalannya proses administrasi di LP Wirogunan. Sistem komputer yang dibutuhkan meliputi sistem informasi narapidana yang dilengkapi proses pengenalan sidik jari. Pengenalan sidik jari menggunakan sistem komputer diperlukan untuk identifikasi narapidana, karena untuk kebutuhan identifikasi sangat dibutuhkan proses yang cepat dan akurat mengingat proses identifikasi konvensional sangat menyita waktu, tenaga dan biaya.

\subsection{Rumusan masalah}

Permasalahan yang dibahas pada penelitian ini adalah bagaimana membangun sebuah sistem komputer yang mampu memberikan informasi serta melakukan proses pengenalan pola sidik jari narapidana sehingga memudahkan proses administrasi pada LP Wirogunan.

\subsection{Batasan masalah}

Dalam melaksanakan suatu penelitian diperlukan adanya batasan-batasan agar tidak menyimpang dari yang telah direncanakan sehingga tujuan yang sebenarnya dapat tercapai. Adapun batasan-batasan tersebut adalah:

1. Metode yang digunakan dalam proses pembelajaran dan pengenalan pola sidik jari adalah JST Learning Vector Quantization.

2. Sidik jari yang diproses adalah sidik jari ibu jari (jempol) dan disimpan dalam format bitmap (bmp).

\subsection{Tujuan dan manfaat penelitian}

a. Merancang sistem komputerisasi pada LP Wirogunan agar dapat memberikan kemampuan mengakses data secara cepat, lengkap dan akurat.

b. Mengaplikasikan algoritma JST dngan metode Learning Vector Quantization dan merancang suatu sistem yang dapat melakukan tugas dalam melakukan pembelajaran serta pengenalan pola sidik jari narapidana.

c. Membantu memberikan solusi pada instansi LP Wirogunan dan guna memecahkan permasalahan, khususnya mengenai sstem informasi manajemen narapidana.

\section{LANDASAN TEORI}

\subsection{Jaringan Syaraf Tiruan LVQ}

Jaringan Syaraf Tiruan (JST) merupakan representasi buatan dari otak manusia yang selalu mencoba mensimulasikan proses pembelajaran pada otak manusia tersebut. Istilah buatan disini digunakan karena jaringan syaraf ini diimplementasikan dengan menggunakan program komputer yang mampu menyelesaikan sejumlah proses perhitungan selama proses pembelajaran (Kusumadewi, 2003). 
Jaringan Syaraf Tiruan memodelkan jaringan syaraf biologis yang terdapat pada otak manusia. Pemodelan terutama hanya didekati dari sudut kmputasinya saja. JST terdiri dari sejumlah simpul (node) yang merupakan elemen pemroses. Setiap simpul tersebut memodelkan sebuah sel saraf biologis (neuron). Hubungan antar simpul dicapai melalui bobot koneksi (weight). Bobot koneksi menentukan apakah sinyal yang mengalir bersifat peredam (inhibitory connection). Bobot koneksi yang bersifat meredam dapat dinyatakan, misalnya oleh bilangan negatif, sedangkan yang bersifat merangsang oleh bilangan positif. Selain ditentukan oleh karakteristik bobot koneksinya, besrnya sinyal yang keluar dari sebuah simpul juga ditentukan oleh fungsi aktifasi (activation function) yang digunakannya.

Artinya, pemilihan fungsi aktifasi menentukan derajat keaktifan dari sebuah simpul (Liman, 2005).

Learning Vector Quantization (LVQ) adalah suatu metode untuk melakukan pembelajaran pada lapisan kompetitif yang terawasi. Suatu lapisan kompetitif akan secara otomatis belajar untuk mengklasifikasikan vektor vektor input. Kelas kelas yang didapatkan sebagai hasil dari lapisan kompetitif ini hanya tergantung pada jarak antara vektor vektor input. Jika 2 vektor input mendekati sama, maka lapisan kompetitif akan meletakkan kedua vektor input tersebut ke dalam kelas yang sama.

\subsection{Sidik Jari}

Sidik jari manusia merupakan bukti materi yang amat penting. Tak ada sidik jari yang identik di dunia ini sekalipun di antara dua saudara kembar. Dalam dunia sains pernah dikemukakan, jika ada 5 juta orang di bumi, kemungkinan munculnya dua sidik jari manusia yang sama baru akan terjadi lagi 300 tahun kemudian.

Sidik jari adalah bentuk alur garis pada bagian ujung jari telapak tangan manusia yang membentuk pola pola tertentu. Dua buah sidik jari yang berasal dari satu sumber akan memiliki alur garis lokal yang sama.

Tidak ada dua individu yang memiliki pola sidik jari yang identik walaupun berasal dari satu indung telur. Hal ini disebabkan karena pola sidik jari yang terbentuk dalam embrio tidak pernah diturunkan. Bila jari seseorang mengalami luka seperti tergores atau sobek maka setelah sembuh, sidik jari yang tergores tersebut akan kembali seperti sedia kala. Sidik jari seseorang tidak akan berubah selama hidupnya dan hanya akn berubah jika seseorang telah meninggal dunia dan terjadi proses penguraian.

Sifat yang dimiliki oleh sidik jari antara lain:

a. Perennial nature, yaitu guratan-guratan pada sidik jari yang melekat pada kulit manusia seumur hidup.

b. Immutability, yaitu sidik jari seseorang tidak pernah berubah, kecuali mendapatkan kecelakaan yang serius.

c. Individuality, pola sidik jari adalah unik dan berbeda untuk setiap orang. 
Klasifikasi sidik jari berdasarkan garis lokal atau karakter anatomi terdiri dari bifurcation, dot, enclose loop, endclose ridge, evading ends, eye island, fork, hock, ridge ending, ridge starting dan specialties.

Belasan alur garis lokal tersebut berguna untuk proses identifikasi, tetapi untuk keperluan tersebut sebenarnya hanya ada dua alur garis yang paling dominan, yaitu garis akhir (ridge ending) dan garis percabangan (ridge bifurcation). Kedua garis tersebut disebut dengan minutiae. Sedangkan titik pada garis akhir, dan titik pertemuan pada garis percabangan ini, disebut dengan end minutiae dan bifurcation minutiae.

\section{PERANCANGAN SISTEM}

\subsection{Penetapan Input}

Penetapan input dilakukan berdasarkan matriks pola sidik jari berukuran $120^{*} 160$ piksel. Dalam hal ini matriks diperoleh dari penelusuran tiap piksel pola sidik jari dimana akan diberi nilai 1 jika terdapat piksel berwarna hitam dan nilai 0 untuk piksel berwarna putih. Dengan demikian dalam satu pola sidik jari akan terdapat 19200 elemen matriks.

\subsection{Penetapan Output}

Output yang akan dihasilkan pada sistem ini adalah kemiripan sidik jari yang diujikan dengan beberapa pola sidik jari yang telah mengalami proses pelatihan. Kemiripan diperoleh dengan menghitung jarak antara matriks pola sidik jari yang diujikan dengan bobot akhir pada tiap tiap pola sidik jari yang telah dilatih. Semakin kecil jarak, maka akan semakin mendekati kemiripan.

\subsection{Arsitektur jaringan}

Inisialisasi bobot ini diperoleh dari data yang diinputkan yang didapat dari hasil penelusuran pola sidik jari hingga menjadi matriks. Setiap pemilik sidik jari akan memasukkan data sidik jari jempol kanan sebanyak lima kali. Dengan demikian setiap kelas sidik jari akan memiliki lima matriks yang berbeda. Matriks pertama akan dijdikan sebagai inisialisasi bobot, sedangkan 4 input sisanya akan digunakan sebagai data yang akan dilatih.

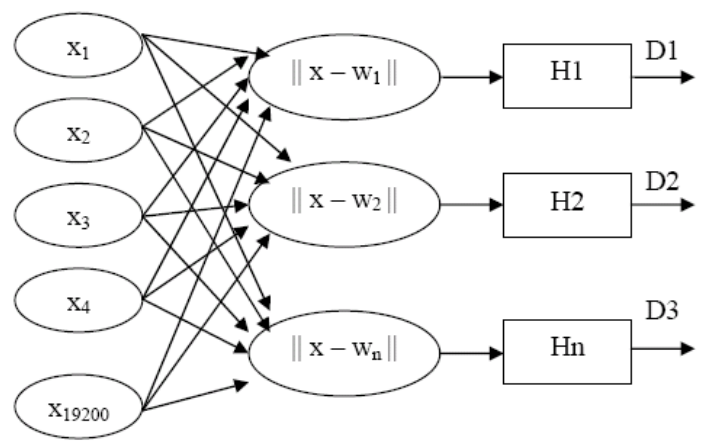

Gambar 1. Arsitektur Jaringan Syaraf Tiruan 
dengan:

$\mathrm{x}_{1}$ sampai dengan $\mathrm{x}_{19200}=$ nilai input

|| $\mathrm{x}-\mathrm{w}_{1}||$ sampai dengan || $\mathrm{x}-\mathrm{w}_{\mathrm{n}}||=$ jarak bobot

H1 sampai dengan $\mathrm{Hn}=$ lapisan output

D1 sampai dengan $\mathrm{Dn}=$ nilai output

$\mathrm{n}=$ jumlah data sidikjari (jumlah kelas)

Gambar 1 merupakan arsitektur rancangan jaringan saraf tiruan dengan menggunakan Learning Vector Quantization dimana $\mathrm{x}_{1}$ sampai dengan $\mathrm{x}_{19200}$ merupakan elemen matriks dalam setiap pola sidik jari yang akan dijadikan sebagai nilai input. Kemudian ||$x-w_{1}||$ sampai dengan ||$x-w_{n}||$ merupakan perhitungan jarak bobot terkecil dengan $\mathrm{w}_{1}$ sampai dengan $\mathrm{w}_{\mathrm{n}}$ adalah nilai data inisialisasi. Sedangkan $\mathrm{H} 1$ sampai dengan $\mathrm{Hn}$ adalah lapisan output dan D1 sampai dengan Dn adalah bobot akhir yang nantinya akan dipakai dalam proses pengujian dengan data sidik jari baru yang dimasukkan.

\section{IMPLEMENTASI DAN PENGUJIAN}

\subsection{Pencarian Sidik jari}

Untuk memulai proses pencarian, terlebih dahulu user harus memasukkan data sidik jari yang ingin dicocokkan. File gambar harus memiliki format bitmap (*.bmp) dan berukuran $120^{*} 160$ piksel. Setelah itu user memasukkan toleransi pencarian yang diinginkan, semakin besar toleransi maka semakin banyak data akan ditampilkan berdasarkan tingkat kemiripan (jarak terkecil dengan bobot).

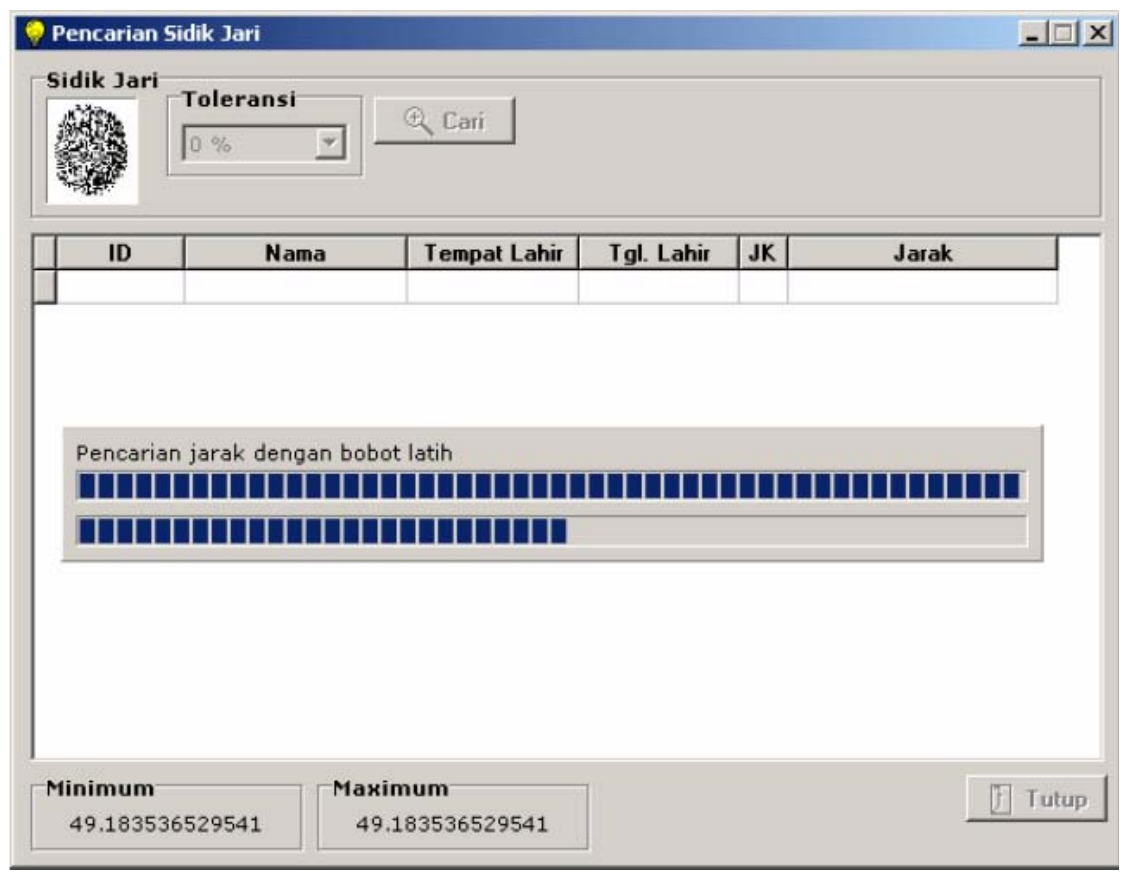

Gambar 2. Implementasi Proses Pencarian Sidik Jari 
Gambar 2 menunjukkan proses implementasi pencarian sidik jari. Jalannya proses ditunjukkan dengan progress bar pada form. Kemudian setelah proses selesai, maka data yang ditemukan akan ditampilkan (gambar 3).

\subsection{Pelatihan LVQ}

Data yang telah dimasukkan didalam database, khususnya data pola sidik jari narapidana harus melalui proses pelatihan. Hal ini diperlukan untuk mencari bobot akhir yang nantinya digunakan untuk proses pencarian sidik jari dengan menghitung jarak antara data yang ingin dicocokkan dengan bobot akhir tersebut.

Adapun proses pelatihan ini membutuhkan waktu tergantung pada jumlah epoh yang digunakan. Semakin besar epoh yang digunakan, semakin lama waktu yang dibutuhkan. Dalam pelatihan terdapat 3 proses yang dilakukan oleh sistem, yaitu proses inisialisasi bobot, proses pelatihan (sampai dengan epoh yang ditentukan), dan proses update data bobot ke database.

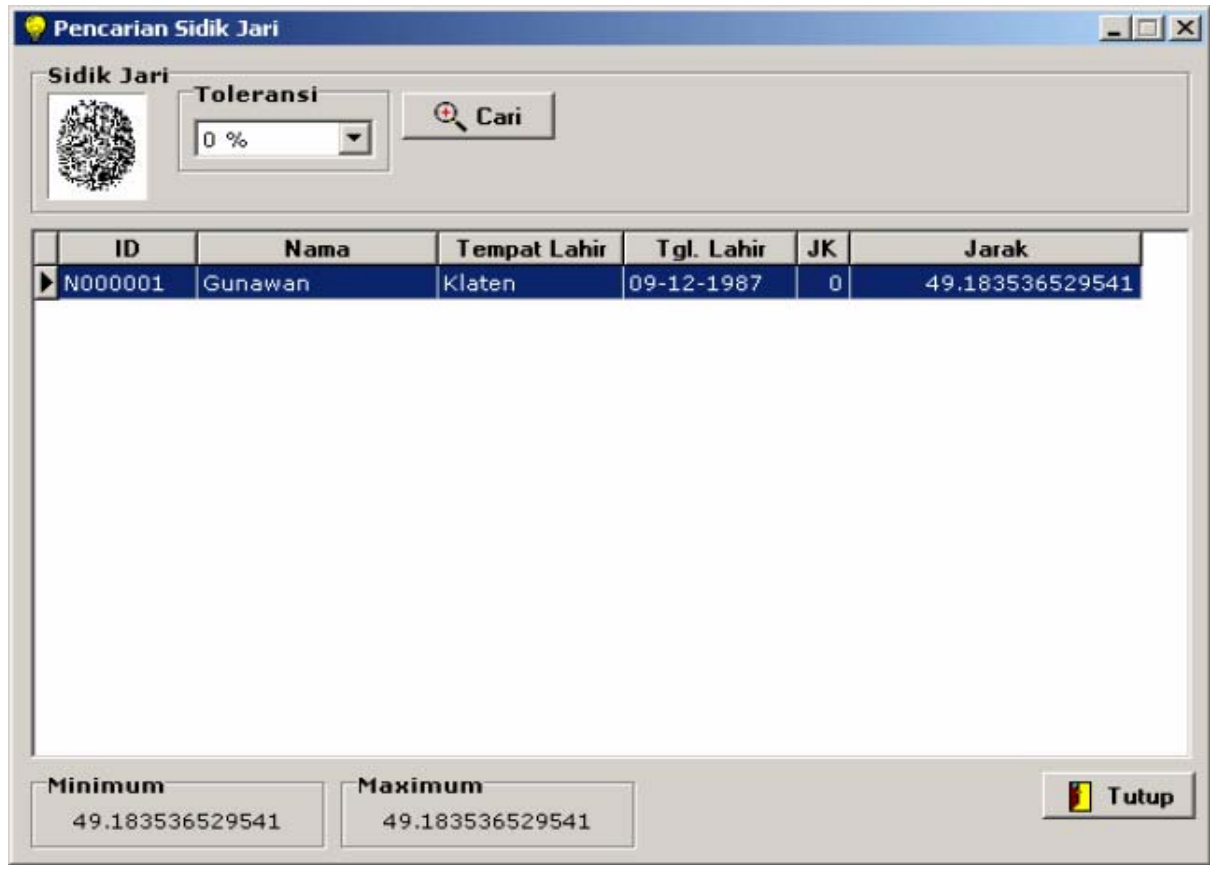

Gambar 3. Implementasi Hasil Pencarian Sidik Jari

Proses pelatihan LVQ meliputi beberapa tahapan dalam implementasinya. Pada saat proses pelatihan dijalankan, maka form akan menunjukkan jalannya proses dengan menggunakan progress bar. Sistem akan memberikan keterangan proses pada setiap tahapan yang dilakukan. Proses peletihan LVQ dapat dilihat pada gambar 4. Kemudian hasil perhitungan pelatihan juga akan ditampilkan setelah proses pelatihan selesai. Contoh tampilan hasil pelatihan dapat dilihat pada gambar 5 . 


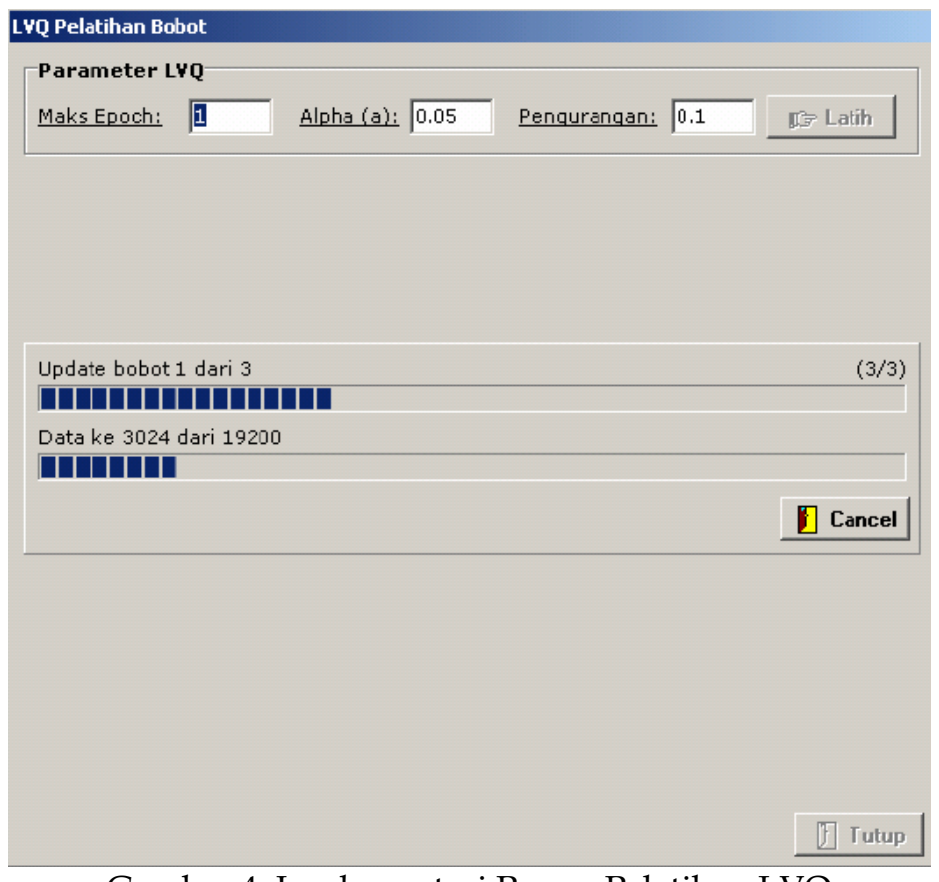

Gambar 4. Implementasi Proses Pelatihan LVQ

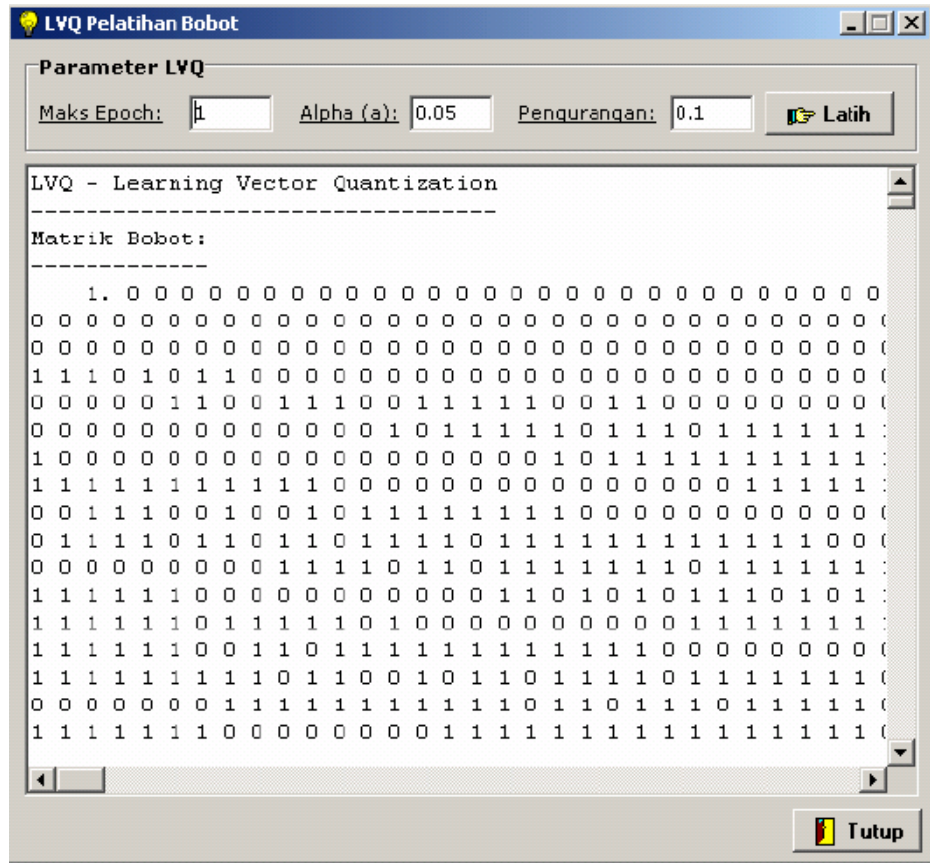

Gambar 5. Implementasi Hasil Pelatihan LVQ 


\subsection{Pengujian}

Pada tahap ini akan dianalisis hasil dari proses perhitungan pelatihan dan proses perhitungan pengujian. Pada proses perhitungan pelatihan digunakan pola sidik jari jempol kanan yang masing masing pola memiliki 5 gambar. Setiap gambar pola memiliki ukuran $120^{*} 160$ piksel dengan format bitmap (hitam-putih). Proses pelatihan menggunakan maksimum epoh 5, 10 dan 20, dengan nilai alpha 0.05 dan nilai pengurangan 0.1. Untuk melakukan analisis data, maka proses pelatihan akan dilakukan sebanyak 9 kali dengan data dan jumlah epoh yang berbeda. Kesembilan kali pelatihan tersebut menggunakan data sebagai berikut:

1. 3 pola dengan 5 epoh

2. 3 pola dengan 10 epoh

3. 3 pola dengan 20 epoh

4. 5 pola dengan 5 epoh

5. 5 pola dengan 10 epoh

6. 5 pola dengan 20 epoh

7. 10 pola dengan 5 epoh

8. 10 pola dengan 10 epoh

9. 10 pola dengan 20 epoh

Waktu yang dibutuhkan untuk melatih pola tersebut tidak sama, berikut tabel waktu yang dibutuhkan dalam proses pelatihan dengan menggunakan spesifikasi perangkat keras $900 \mathrm{MHz}$ prosesor dan $128 \mathrm{Mb}$ RAM:

Tabel 1. Waktu Pelatihan (900 MHz / $128 \mathrm{Mb})$

\begin{tabular}{|c|c|c|c|}
\hline No. & Maximum Epoh & Jumlah Pola & Waktu yang diperlukan (menit) \\
\hline 1. & 5 & 3 & $12: 37: 289$ \\
\hline 2. & 10 & 3 & $17: 28: 209$ \\
\hline 3. & 20 & 3 & $33: 24: 061$ \\
\hline 4. & 5 & 5 & $16: 39: 480$ \\
\hline 5. & 10 & 5 & $23: 01: 352$ \\
\hline 6. & 20 & 5 & $57: 28: 532$ \\
\hline
\end{tabular}

Perbandingan Waktu Pelatihan

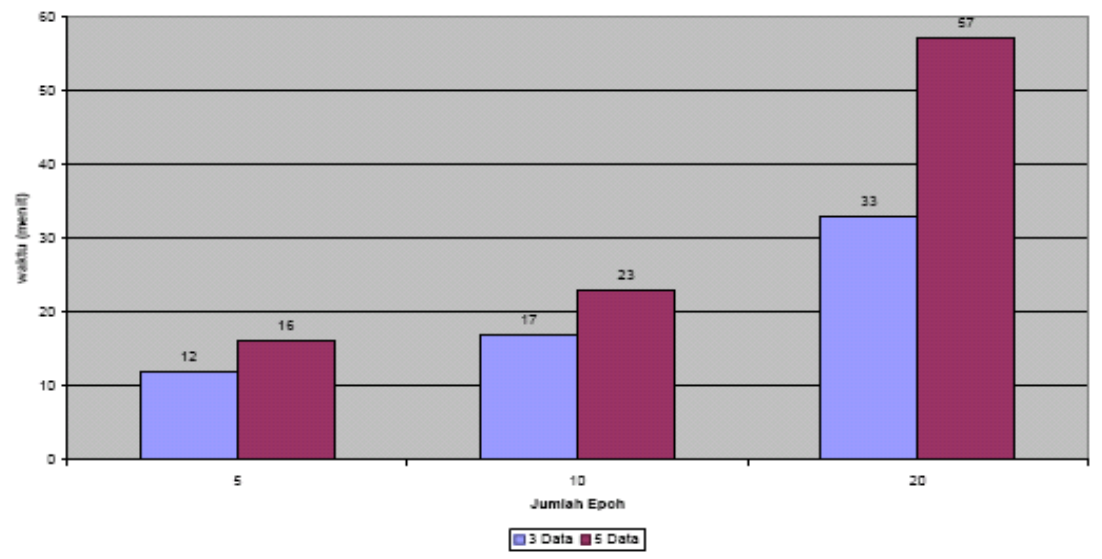

Gambar 6. Grafik Perbandingan Waktu Pelatihan 
Dari tabel 1 dapat dilihat bahwa jumlah epoh dan jumlah pola akan berbanding lurus dengan waktu yang diperlukan. Dalam arti, bahwa akan semakin lama waktu yang dibutuhkan jika jumlah epoh dan jumlah data semakin besar. Grafik perbandingan waktu dapat dilihat pada gambar 6 .

Dari data data diatas memang dapat dilihat bahwa proses pelatihan menggunakan LVQ memerlukan waktu yang lama. Hal ini dikarenakan proses iterasi yang memakan waktu pada tiap iterasinya. Selain itu proses update bobot juga membutuhkan waktu untuk melakukan input bobot latih sebanyak 19200 data tiap pola.

Setelah dilatih menggunakan spesifikasi hardware rendah, maka selanjutnya akan dianalisis jika menggunakan spesifikasi perangkat keras $1.8 \mathrm{GHz}$ Prosesor dan 1Gb RAM. Maka perhitungan waktunya dapat dilihat pada tabel 2.

Tabel 2. Waktu Pelatihan (1800 MHz / $1024 \mathrm{Mb})$

\begin{tabular}{|c|c|c|c|}
\hline No. & Maximum Epoh & Jumlah Pola & Waktu yang diperlukan (menit) \\
\hline 1. & 5 & 3 & $04: 52: 163$ \\
\hline 2. & 10 & 3 & $07: 01: 453$ \\
\hline 3. & 20 & 3 & $08: 41: 427$ \\
\hline 4. & 5 & 5 & $08: 23: 843$ \\
\hline 5. & 10 & 5 & $13: 35: 538$ \\
\hline 6. & 20 & 5 & $23: 32: 532$ \\
\hline
\end{tabular}

Dengan melihat tabel 1 dan tabel 2, maka akan terlihat perbedaan yang sangat signifikan dari jumlah waktu yang diperlukan. Spesifikasi perangkat keras yang tinggi akan sangat berpengaruh pada penghematan waktu pelatihan. Gambar 7 menunjukkan perbedaan waktu yang dibutuhkan jika menggunakan dua spesifikasi perangkat keras yang berbeda.

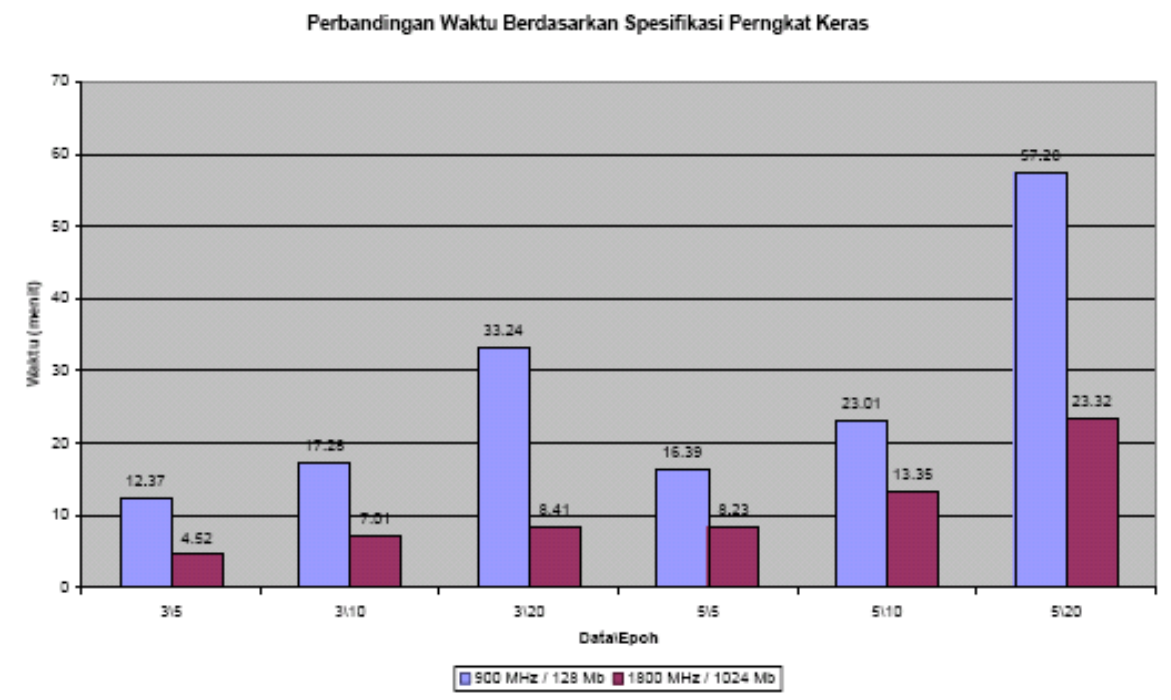

Gambar 7. Grafik Perbandingan Waktu Pelatihan Berdasarkan Spesifikasi Perangkat Keras 
Kemudian pada proses perhitungan pengujian akan dimasukkan data pola sidik jari untuk dicocokkan, dengan ketentuan gambar seperti pada proses pelatihan. Adapun waktu yang diperlukan untuk proses pengujian sidik jari dapat dilihat pada tabel 3 .

Seperti pada proses pelatihan, analisis juga dilakukan terhadap waktu yang dibutuhkan untuk proses pengujian dengan spesifikasi perangkat keras yang lebih tinggi. Hasil analisis dapat dilihat pada tabel 4.

Tabel 3. Waktu Pengujian (900 MHz / $128 \mathrm{Mb})$

\begin{tabular}{|c|c|c|}
\hline No. & Jumlah Pola pada Database & Waktu yang diperlukan (menit) \\
\hline 1. & 3 & $00: 28: 209$ \\
\hline 2. & 5 & $01: 35: 104$ \\
\hline 3. & 10 & $03: 09: 950$ \\
\hline
\end{tabular}

Tabel 4. Waktu Pengujian (1800 MHz / $1024 \mathrm{Mb})$

\begin{tabular}{|c|c|c|}
\hline No. & Jumlah Pola pada Database & Waktu yang diperlukan (menit) \\
\hline 1. & 3 & $00: 23: 930$ \\
\hline 2. & 5 & $00: 39: 780$ \\
\hline 3. & 10 & $01: 17: 880$ \\
\hline
\end{tabular}

Perbandingan Waktu Pengujian

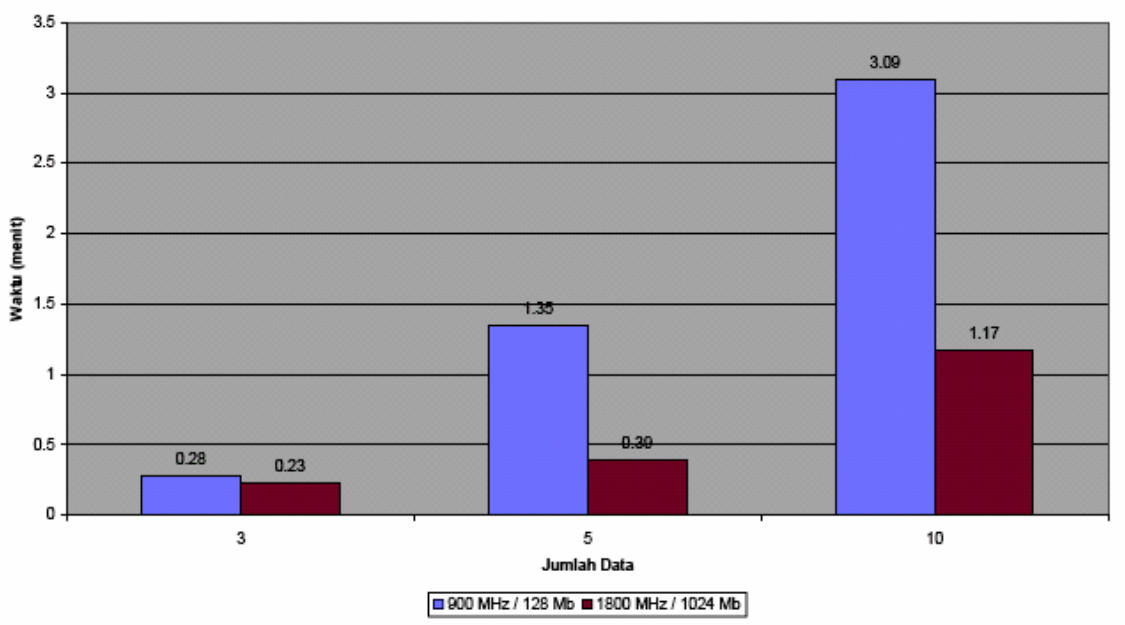

Gambar 8. Grafik Perbandingan Waktu Pengujian

Tabel 5. Hasil Pengujian (Pola ikut dilatih)

\begin{tabular}{|c|c|c|c|}
\hline No. & Maximum Epoh & Jarak terdekat dengan & Jarak \\
\hline 1. & 5 & Jon & 35,8651466369629 \\
\hline 2. & 10 & Jon & 33,1454772949219 \\
\hline 3. & 20 & Jon & 30,6464614868164 \\
\hline
\end{tabular}


Tabel 6. Hasil Pengujian (Pola tidak ikut dilatih)

\begin{tabular}{|c|c|c|c|}
\hline No. & Maximum Epoh & Jarak terdekat dengan & Jarak \\
\hline 1. & 5 & Jon & 37,3176696777344 \\
\hline 2. & 10 & Jon & 36,5154609680176 \\
\hline 3. & 20 & Jon & 35,1000061035156 \\
\hline
\end{tabular}

Dari gambar 8 juga dapat dilihat bahwa penggunaan perangkat keras yang memiliki spesifikasi tinggi akan berengaruh secara signifikan terhadap penghematahn waktu pengujian. Pada analisis terhadap proses pengujian berikut akan diujikan pola sidik jari yang ikut dilatih dan pola sidik jari yang tidak dikenali (tidak ikut dilatih). Dalam analisis ini akan diambil sidik jari milik Jon.

Dari tabel 5 dan tabel 6 dapat dilihat bahwa semakin besar epoh yang digunakan dalam pelatihan, maka jarak yang didapatkan dalam proses pengujian akan semakin kecil. Kemudian juga terdapat perbedaan jarak antara pengujian menggunakan data yang ikut dilatih (dikenali) dengan pengujian menggunakan data yang tidak ikut dilatih (tidak dikenali). Gambar 9 menunjukkan grafik perbandingan jarak.

Perbandingan Jarak

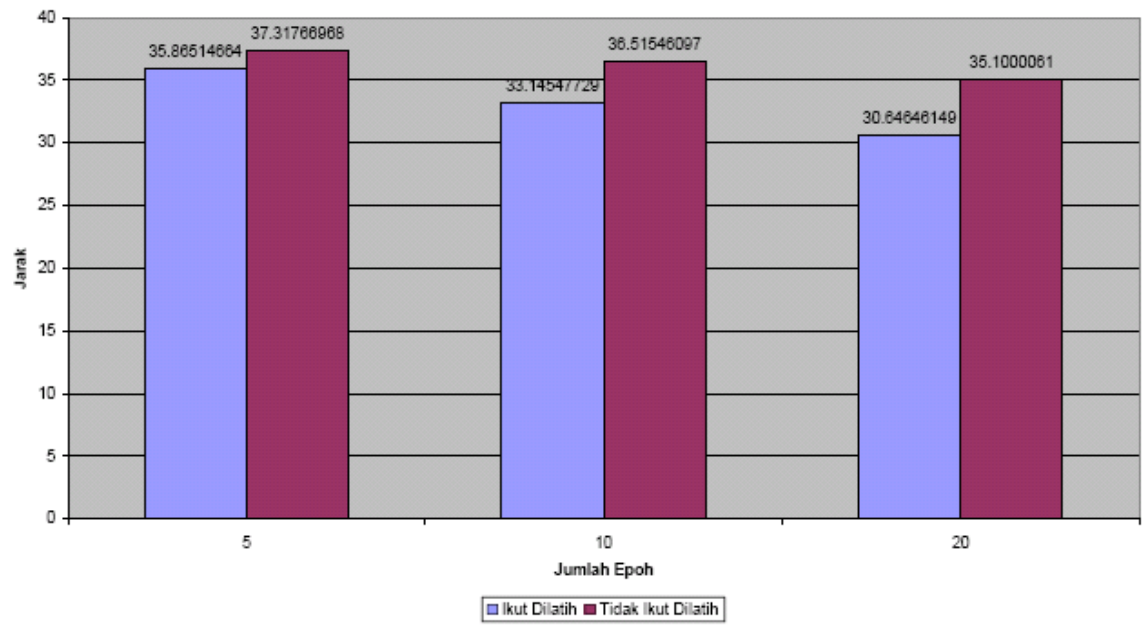

Gambar 9. Grafik Perbandingan Jarak

Setelah melakukan analisis terhadap perbandingan jarak antara data yang ikut dilatih dengan data yang tidak ikut dilatih, maka analisis berikutnya akan difokuskan pada keberhasilan pencocokkan pola sidik jari yang tidak ikut dilatih. Akan dicocokkan 5 pola sidik jari yang tidak ikut dilatih, pengujian dilakukan terhadap database yang memiliki 10 data dengan jumlah epoh 20.

Pada setiap proses pencocokkan akan menggunakan prosentase toleransi. Nilai prosentase akan dikalikan dengan selisih antara jarak minimum dengan jarak maksimum dari hasil pengujian. Hasil perkalian tersebut akan dijadikan range dari jarak minimum untuk menentukan pola sidik jari yang dianggap memiliki kemiripan. Sebagai contoh, jika menggunakan prosentase toleransi 
kemiripan $10 \%$ dan ditemukan jarak minimum adalah 2 dan maksimum adalah 8 . Maka range yang akan digunakan adalah $10 \% \times(8-2)=0,6$. Sehingga pola sidik jari yang dianggap memiliki kemiripan adalah pola yang memiliki jarak dengan bobot latih antara 2 sampai dengan 2,6 $(2+0,6)$.

Pada analisis pertama akan dicocokkan 5 pola sidik jari yang tidak dikenali, dengan menggunakan prosentase toleransi $0 \%$.

Tabel 7. Hasil Pengujian (Toleransi 0\%)

\begin{tabular}{|c|c|c|c|}
\hline Pola & Ditemukan & Urutan & Selisih jarak dengan urutan 1 \\
\hline An & Tidak & - & - \\
\hline DA & Tidak & - & - \\
\hline Pur & Ya & 1 & 0 \\
\hline Jon & Ya & 1 & 0 \\
\hline Son & Ya & 1 & 0 \\
\hline
\end{tabular}

Tabel 8. Hasil Pengujian (Toleransi 10\%)

\begin{tabular}{|c|c|c|c|}
\hline Pola & Ditemukan & Urutan & Selisih jarak dengan urutan 1 \\
\hline An & Tidak & - & - \\
\hline DA & Ya & 2 & 0,28557205 \\
\hline Pur & Ya & 1 & 0 \\
\hline Jon & Ya & 1 & 0 \\
\hline Son & Ya & 1 & 0 \\
\hline
\end{tabular}

Tabel 9. Hasil Pengujian (Toleransi 30\%)

\begin{tabular}{|c|c|c|c|}
\hline Pola & Ditemukan & Urutan & Selisih jarak dengan urutan 1 \\
\hline An & Ya & 2 & 5,02647781 \\
\hline DA & Ya & 2 & 0,28557205 \\
\hline Pur & Ya & 1 & 0 \\
\hline Jon & Ya & 1 & 0 \\
\hline Son & Ya & 1 & 0 \\
\hline
\end{tabular}

Dari tabel 7, tabel 8, dan tabel 9 dapat dilihat bahwa dengan hanya dengan menggunakan prosentase toleransi sebesar 30\%, maka keberhasilan menemukan pola sidik jari yang dicari mencapai $100 \%$.

Dari data disebutkan bahwa dari 5 pola yang diujiakan, hanya terdapat 3 pola yang ditemukan. Maka nilai keberhasilan dengan menggunakan toleransi $0 \%$ adalah sebesar $60 \%$.

Dengan melihat tabel 8, maka dapat diketahui bahwa dari 5 pola yang diujikan dengan menggunakan toleransi sebesar $10 \%$ terdapat 4 pola yang ditemukan. Dari data tersebut dapat diprosentasekan keberhasilan pencocokan sebesar $80 \%$.

Setelah dua kali pengujian menggunakan toleransi yang berbeda dan belum mencapai keberhasilan $100 \%$, maka setelah pengujian menggunakan toleransi $30 \%$, nilai keberhasilan dapat mencapai $100 \%$. 
Keberhasilan 100\% disini dimaksudkan bahwa dari kelima data yang diujikan, kelima data tersebut dapat ditemukan meskipun tidak berada pada urutan pertama. Hal ini dikarenakan adanya kemiripan antara data yang dicocokkan, dengan data yang lain (urutan sebelumnya pada hasil pengujian).

Setelah melakukan pengujian berdasarkan nilai toleransi yang digunakan, berikutnya akan dilakukan pengujian berdasarkan jumlah epoh yang digunakan. Pengujian dilakukan dengan menggunakan pola sidik jari yang tidak ikut dilatih (tidak dikenali). Pola tersebut akan dicocokkan dengan bobot yang telah dilatih menggunakan jumlah epoh yang berbeda.

Tabel 10. Hasil Pengujian (5 epoh)

\begin{tabular}{|c|c|c|}
\hline Pola & Ditemukan & Jarak \\
\hline An & Tidak & - \\
\hline DA & Tidak & - \\
\hline Pur & Ya & 45,05432 \\
\hline Jon & Ya & 37,31766 \\
\hline Son & Ya & 39,58343 \\
\hline
\end{tabular}

Tabel 10 menunjukkan hasil pengenalan sidik jari jika bobot dalam database dilatih menggunakan maksimal epoh 5 . hanya terdapat 3 pola yang dikenali dari 5 pola yang diujiakan $(60 \%)$.

Tabel 11. Hasil Pengujian (10 epoh)

\begin{tabular}{|c|c|c|}
\hline Pola & Ditemukan & Jarak \\
\hline An & Tidak & - \\
\hline DA & Tidak & - \\
\hline Pur & Ya & 43,15533 \\
\hline Jon & Ya & 36,51546 \\
\hline Son & Ya & 37,53911 \\
\hline
\end{tabular}

Tabel 11 menunjukkan hasil pengujian menggunakan maksimum epoh 10 . Seperti halnya yang dapat dilihat pada tabel 6.10, pada hasil pengujian ini hanya terdapat 3 pola yang ditemukan dari 5 pola yang diuji.

Tabel 12. Hasil Pengujian (20 epoh)

\begin{tabular}{|c|c|c|}
\hline Pola & Ditemukan & Jarak \\
\hline An & Tidak & - \\
\hline DA & Tidak & - \\
\hline Pur & Ya & 42,42417 \\
\hline Jon & Ya & 35,10000 \\
\hline Son & Ya & 35,69667 \\
\hline
\end{tabular}

Penambahan jumlah epoh dalam pelatihan, tidak merubah nilai keberhasilan dalam mengenali pola sidik jari. Seprti ditunjukkan pada tabel 12, 
dengan menggunakan epoh sebesar 20 keberhasilan menemukan pola tetap pada angka $60 \%$. Hanya saja terdapat perbedaan nilai jarak antara pengujian dengan jumlah epoh yang berbeda.

Jika jumlah epoh tidak begitu berpengaruh pada hasil pengujian, maka selanjutnya pengujian akan dilakukan terhadap nilai alpha (a) yang digunakan.

Tabel 13. Hasil Pengujian $(\alpha=0,05)$

\begin{tabular}{|c|c|c|}
\hline Pola & Ditemukan & Jarak \\
\hline An & Tidak & - \\
\hline DA & Tidak & - \\
\hline Pur & Ya & 42,42417 \\
\hline Jon & Ya & 35,10000 \\
\hline Son & Ya & 35,69667 \\
\hline
\end{tabular}

Tabel 14. Hasil Pengujian $(\alpha=0,5)$

\begin{tabular}{|c|c|c|}
\hline Pola & Ditemukan & Jarak \\
\hline An & Tidak & - \\
\hline DA & Tidak & - \\
\hline Pur & Tidak & - \\
\hline Jon & Ya & 257663,1875 \\
\hline Son & Tidak & - \\
\hline
\end{tabular}

Dari tabel 13 dan tabel 14 di atas dapat dilihat bahwa nilai alpha (a) sangat berpengaruh terhadap hasil pengujian/pengenalan pola. Dengan menggunakan nilai alpha (a) yang lebih besar $(0,5)$, maka nilai keberhasilan akan semakin kecil $(20 \%)$

Pengujian pengenalan pola sidik jari juga dilakukan terhadap pola yang memiliki posisi diluar kewajaran. Dari posisi tersebut nantinya akan diketahui apakh pola tersebut dapat dikenali dengan menggunakan posisi yang berbeda.

Tabel 15 menunjukkan bahwa pola tidaka akan ditemukan jika posisi pola tidak tegak lurus.

Tabel 15. Hasil Pengujian (Terhadap Posisi Pola)

\begin{tabular}{|c|c|c|}
\hline Posisi Pola & Ditemukan & Jarak \\
\hline Diputar $90^{\circ}$ & Tidak & - \\
\hline Diputar $180^{\circ}$ & Ya & $32,93315-$ \\
\hline Diputar $270^{\circ}$ & Tidak & - \\
\hline
\end{tabular}

\section{SIMPULAN DAN SARAN}

\subsection{Simpulan}

Dari pembuatan aplikasi sistem informasi narapidana LP Wirogunan yang dilengkapi pengenal pola sidik jari dapat disimpulkan bahwa:

1. Penggunaan sistem informasi dala proses administrasi narapidana LP Wirogunan akan memudahkan petugas dalam mengolah data narapidana. 
2. Penggunaan desain interface yang user friendly serta berbasis windows memberikan kemudahan bagi petugas dalam proses aplikasi.

3. Petugas juga dapat langsung melakukan proses pencarian data narapidana dengan menggunakan kata kunci ataupun dengan pola sidik jari.

4. Dengan adanya sistem informasi ini diharapkan berpengaruh pada peningkatan mutu dan pelayanan LP Wirogunan.

5. Dengan menggunakan metode Learning Vector Quantization untuk pengenal pola sidik jari, nilai keberhasilan yang diperoleh mencapai $60 \%$.

6. Dengan menggunakan metode LVQ, proses pecarian akan selalu berhasil menemukan data meskipun data yang dimaksud tidak terdapat dalam basis data. Hal ini dikarenakan pencarian didasarkan atas kemiripan dengan data input pencarian. Dari analisis diatas dapat juga disimpulkan bahwa metode tersebut belum layak digunakan untuk proses pencarian, namun metode tersebut dapat digunakan untuk proses pengenalan/pencocokan pola sidik jari.

7. Pencocokan dari hasil pelatihan yang menggunakan jumlah epoh yang lebih kecil akan menghasilkan jarak yang lebih besar. Hal tersebut dapat dilihat pada grafik perbandingan jarak (Gambar 11).

8. Hasil pengujian terhadap data yang tidak ikut dilatih mendapatkan jarak yang lebih besar daripada pengujian terhadap data yang ikut dilatih (Gambar 11).

\subsection{Saran}

1. Untuk kedepannya aplikasi bisa dilengkapi hardware pendukung seperti mesin scan sidik jari dan kamera digital yang terkoneksi langsung dengan sistem informasi.

2. Mengingat lamanya proses pelatihan menggunakan metode LVQ dan dengan epoh yang ideal, maka dibutuhkan suatu mesin komputer yang memiliki kemampuan lebih dalam menangani proses perhitungan .

3. Diharapkan nantinya dikembangkan untuk proses pengenalan pola sidik jari, jika pola yang akan dikenali tidak dalam posisi tegak (miring).

\section{PUSTAKA}

Kustanto, Andri. (2003). Perancangan Sistem Informasi dan Aplikasinya. Penerbit Gaya Media: Yogyakarta.

Gordon B, Davis. (1982). Sistem Informasi Manajemen. PT Pustaka Binamas Presindo: Jakarta.

Jogiyanto, HM. (1991). Analisis dan Desain Sistem Informasi: Pendekatan Terstruktur Teori dan Praktek Aplikasi Bisnis. Andi Offset: Yogyakarta.

Kusumadewi, Sri. (2003). Artificial Intellegence (Teknik dan Aplikasinya). Jogjakarta: Graha Ilmu.

Liman, J. (2005). Feedforward Neural Network. www.ukrida.co.id, diakses tanggal 27 November 2005.

Sommerville, I. (2003). Software Engineering (Rekayasa Perangkat Lunak). Terjemahan Dra. Yuhilza Hanum, M.Eng. Jakarta: Erlangga.

Simatupang M, Togar. (1995). Teori Sistem. Penerbit Andi Offset: Yogyakarta. 